\title{
New records of the critically endangered Squatina squatina (Linnaeus, 1758) from Corsica, France
}

\author{
Matthieu LAPINSKI ${ }^{1}$ and Ioannis GIOVOS ${ }^{2}$ \\ ${ }^{1}$ AILERONS, Environmental Organisation for the Preservation of cartilaginous fish of the \\ French Mediterranean coast, Montpellier, France
}

${ }^{2}$ iSea, Environmental Organisation for the Preservation of the Aquatic Ecosystems, Thessaloniki, Greece

Corresponding author, e-mail: ioannis.giovos@isea.com.gr

\begin{abstract}
Angel Sharks are among the most threatened families of fish in the world. In the Mediterranean three species are present facing a severe depletion with several local extinction events as a result of overexploitation by fisheries. Hereby, we present 7 additional records of Squatina squatina from Corsica contributing to the new regional action plan for Angel Sharks in the Mediterranean Sea. Most records include juvenile specimens, indicating that the area might be a nursery ground for the species.
\end{abstract}

Key words: Angel Sharks, Mediterranean, elasmobranchs, Ligurian Sea, Tyrrhenian Sea

\section{INTRODUCTION}

Angel Sharks (Squatinidae) are the third most threatened family of elasmobranchs in the world after Rhino Rays and Sawfishes (Pristidae) (DULVY et al., 2014; IUCN, 2019). The intensification of commercial fisheries and to a lesser extent recreational fisheries and habitat degradation combined with their life characteristics (i.e. slow growth, low reproductive rate and demersal nature) are the main reasons that brought members of Squatinidae family on the verge of extinction (DULVY et al., 2014; GORDON et al., 2017). In the Mediterranean Sea, 3 species of Angel Sharks occur; the sawback angelshark (Squatina aculeata Cuvier, 1829), the smooth- back angelshark (Squatina oculata Bonaparte, 1840) and the angelshark (Squatina squatina Linnaeus, 1758), all listed as Critically Endangered in the IUCN Red List of Threatened Species (IUCN, 2018), due to their steep population decline and several local extinctions, (FERRETI et al., 2016; SOLDO \& BARICHE, 2016; MOREY et al., 2019).

The French waters historically, were part of the Squatina spp. range in the Mediterranean Sea (GORDON et al., 2017). This is confirmed by the fact that French fishers had a modified type of net that were used to catch Angel Sharks in the French waters, the so called "martramaux" (QUERO \& CENDRERO, 1995). In addition, one area in south of France close to Nice is named 


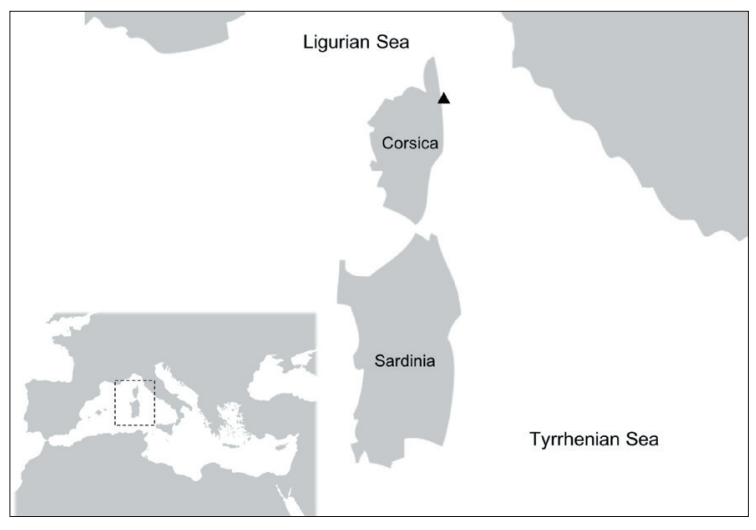

Fig. 1. Location (triangle) where 7 individuals of Squatina squatina were caught by the professional fisherman.

"la Baie des Anges" which literally means the "Angel's bay" because this area used to be inhabited by Angel Sharks until the end of the $20^{\text {th }}$ century. Recently, landings of Squatina spp. are absent in the official and the reconstructed landing statistics for the Mediterranean coast of France (GIOVOS et al., 2019), while records from French mainland are completely absent, with the only recent published record of Squatina squatina coming from Corsica (BAINO et al., 2001). To date, S. squatina is the only shark species officially listed as critically endangered in the French list of endangered species (MNHN \& IUCN, 2013).

Hereby we present another 7 additional records of Squatina squatina from Corsica island reported between 2017 and 2018 suggesting this area is a critical habitat for the species. We discuss our findings under the Eastern Atlantic and Mediterranean Angel Shark Conservation Strategy and with the aim to contribute to the Angel Shark Conservation Network and the new Mediterranean Angel Sharks Action Plan that is about to be published.

\section{MATERIAL AND METHODS}

A professional fisherman from Corsica (Fig. 1), reported sightings of Angel Sharks to Association Ailerons (http://asso-ailerons.fr/), providing photographic evidences of the specimens (Fig. 2) through a French citizen science program. The images checked for their authenticity and originality using the automatic image rec-

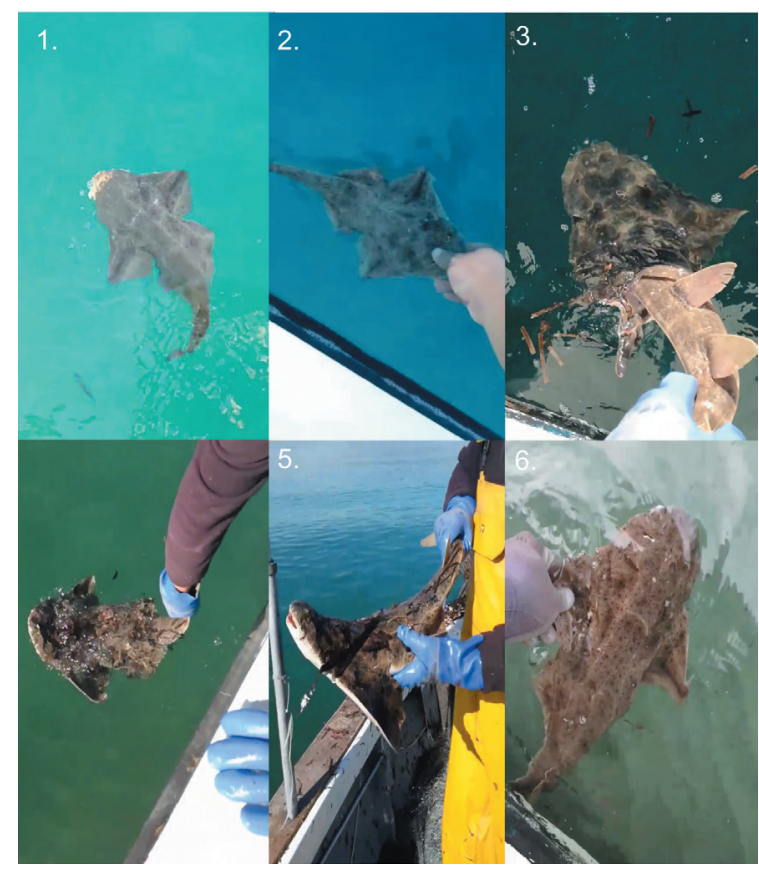

Fig. 2. Photos of Squatina squatina individuals captured and released in Corsica, France between 2017-2018. Numbers on the photos correspond to the code provided in Table 1.

ognition tool of Google. Additional information about the exact location, the depth of the observations, the approximate size of the individuals, the equipment used and the time that the individuals captured were also registered.

\section{RESULTS}

In Table 1 are presented all the details regarding the sightings of Squatina squatina provided by the fisherman and in Fig. 2 the location of the observations. All observations are located outside the lagoon of the Réserve Naturelle de l'Etang de Biguglia an area covered with sandy bottom and meadows of Posidonia oceanica (L.) Delile, 1813. The fisherman used trammel nets that deployed at very low depth during the evening and recover during the first morning hours. All individuals were alive once reached the boat speculating that the captures took place during the first morning hours. All individuals were released alive. 
Table 1 .

\begin{tabular}{|c|c|c|c|c|c|}
\hline Date & Coordinates & Species & $\begin{array}{c}\text { Picture } \\
\text { Code }\end{array}$ & Size & Depth \\
\hline $19 / 06 / 2017$ & $42^{\circ} 34.927^{\prime} \mathrm{N}, 9^{\circ} 31.135^{\prime} \mathrm{E}$ & Squatina squatina & 1 & $50 \mathrm{~cm}$ & $<5 \mathrm{~m}$ \\
\hline $20 / 06 / 2017$ & $42^{\circ} 34.927^{\prime} \mathrm{N}, 9^{\circ} 31.135^{\prime} \mathrm{E}$ & Squatina squatina & 2 & $40 \mathrm{~cm}$ & $<5 \mathrm{~m}$ \\
\hline $26 / 10 / 2017$ & $42^{\circ} 34.927^{\prime} \mathrm{N}, 9^{\circ} 31.135^{\prime} \mathrm{E}$ & Squatina squatina & 3 & $120 \mathrm{~cm}$ & $<5 \mathrm{~m}$ \\
\hline $07 / 04 / 2018$ & $42^{\circ} 34.927^{\prime} \mathrm{N}, 9^{\circ} 31.135^{\prime} \mathrm{E}$ & Squatina squatina & 4 & $80 \mathrm{~cm}$ & $<5 \mathrm{~m}$ \\
\hline $07 / 04 / 2018$ & $42^{\circ} 34.927^{\prime} \mathrm{N}, 9^{\circ} 31.135^{\prime} \mathrm{E}$ & Squatina squatina & 5 & $80 \mathrm{~cm}$ & $<5 \mathrm{~m}$ \\
\hline $07 / 05 / 2018$ & $42^{\circ} 34.927^{\prime} \mathrm{N}, 9^{\circ} 31.135^{\prime} \mathrm{E}$ & Squatina squatina & 6 & $60 \mathrm{~cm}$ & $<5 \mathrm{~m}$ \\
\hline $09 / 05 / 2018$ & $42^{\circ} 34.927^{\prime} \mathrm{N}, 9^{\circ} 31.135^{\prime} \mathrm{E}$ & Squatina squatina & - & - & $<5 \mathrm{~m}$ \\
\hline
\end{tabular}

\section{DISCUSSION}

Corsica is the only location within the Mediterranean territories of France that Squatina squatina is considered still present (GORDON et al., 2017; MOREY et al., 2019). Our records together with recent observation (BAINO et al., 2001) confirm the species presence in the island. Although the records are coming from the same fisher from the same location and the individuals released alive is possible that some individuals are recaptures. However, this does not underestimate the importance of our findings given that in Fig. 1 of GORDON et al., (2017) no records of juveniles included from Corsica. In this work we present 3, potentially 5, records of juveniles Squatina squatina based on the work by LIPEJ et al. (2004) in which is described that females reach maturity at $128-169 \mathrm{~cm}$ total length (TL), and males at $80-132 \mathrm{~cm}$ TL (see Table 1). While, according to the work by CAPAPÉ et al. (1990), some of them might have been the young of the year, given the reported size by the fisherman and associated scalable pictures (see Table 1 and Fig. 2). This is of particular importance for the conservation of the species in the Mediterranean, as the identification and the protection of the reproductive, nesting and nursery grounds is a top priority, also identified in Goal 2 of the action plan (GORDON et al., 2017).

Angel Sharks, once abundant in the Mediterranean, now appeared to be fragmented and severely depleted. Recently many occurrences of all three species throughout the Mediterranean have been published (ALKUSAIRY \& SAAD,
2018; GIOVOS et al., 2019 and all references within; ERGUDEN et al., 2019; RAFRAFI-NOUIRA et al., 2019; ANGEL SHARK CONSERVATION NETWORK, 2019) leaving a glimpse of hope regarding the species survival. On the other hand, the increasing amount of the species observations might be related to the increasing use of social media, the existence of several citizen science projects targeting elasmobranchs in the Mediterranean and finally the growing number of organisations that work on elasmobranch conservation. In all cases, the conservation of the species is of high priority and extremely urgent, given their conservation status.

"Recently a workshop took place in Tunis (Tunisia) coordinated by the Angel Shark Conservation Network (https://angelsharknetwork.com/) for preparing the new regional action plan for Angel Sharks in the Mediterranean Sea (Gordon et al., 2019). The workshop concluded that although Angel Sharks are protected in the Mediterranean, as they are listed on Annex II of the Barcelona Convention (GFCM/36/2012/3 now GCFM/42/2018/2), still the law enforcement is poor and insufficient to protect these species that are in the verge of extinction This is further reflected in the Action Plan as an underlying goal "National legislation for angel sharks is established, implemented and enforced" (GORDON et al., 2019)." In addition, is clear that still severe gaps exist in our knowledge regarding the species distribution, biology and ecology in the Mediterranean Sea. Thus, efforts must be made to close these gaps for advancing the conservation of these species 
by applying sound policies. Our work wants to contribute towards this end by providing important observations of Squatina squatina in an area that appeared to be critical for the survival of the species in the basin.

\section{ACKNOWLEDGEMENTS}

We would like to warmly thank the anonymous fisherman for providing his observation and being always helpful and collaborative and the Editor and two reviewers that improved the publication with their constructive comments.

\section{REFERENCES}

ALKUSIARY, H. \& A. SAAD. 2018. Species composition, diversity and length frequency of by-catch sharks from the Syrian coast. Int. J. Res. Stud. Zool., 4: 11-21.

ANGEL SHARK CONSERVATION NETWORK. 2019. Angel Shark Sighting Map. Retrieved on 05/08/2019 from: https://angelsharknetwork. com/\#map

BAINO, R., F. SERENA, S. RAGONESE, J. REY. \& P. RINELLI. 2001. Catch composition and abundance of elasmobranchs based on the MEDITS program. Rapp. Comm. Int. Mer. Medit., 36: p. 234.

CAPAPÉ, C., J.P. QUIGNARD \& J. MELLINGER. 1990. Reproduction and development of two angel sharks, Squatina squatina and S. oculata (Pisces: Squatinidae), of Tunisian coasts: semi-delayed vitellogenesis, lack of egg capsules, and lecithotrophy. J. Fish Biol., 37: 347-356.

DULVY, N.K., S.L. FOWLER, J.A. MUSICK, R.D. CAVANAGH, P.M. KYNE, L.R. HARRISON \& W.T. WHITE. 2014. Extinction risk and conservation of the world's sharks and rays. eLife, 3: e00590. https://doi.org/10.7554/eLife.00590

FERRETTI, F., G. MOREY, F. SERENA, C. MANCUSI, R.P. COELHO, M. SEISAY \& E. BUSCHER. 2016. Squatina oculata. The IUCN Red List of Threatened Species 2016: e.T61418A16570000. Downloaded on 15 April 2018.

GIOVOS, I., V.O. STOILAS, S.A. AL-MABRUK, N. DOUMPAS, P. MARAKIS, M. MAXIMIADI, D. MOUTOPOULOS, P. KLEITOU, I. KERAMIDAS, F. TIRALONGO \& A. DE MADDALENA. 2019. Integrating local ecological knowledge, citizen science and long-term historical data for endangered species conservation: Addi- tional records of angel sharks (Chondrichthyes: Squatinidae) in the Mediterranean Sea. Aquatic Conservation: Marine and Freshwater Ecosystems. 29 (6):881-890.

GORDON, C.A., A.R. HOOD, J. BARKER, À. BARTOLI, N.K. DULVY, D. JIMENEZ ALVARADO, J.M. LAWSON \& E.K.M. MEYERS. 2017. Eastern Atlantic and Mediterranean Angel Shark Conservation Strategy. The Shark Trust, pp. 1-8.

GORDON, C.A., A.R. HOOD, S. A. A. AL MABRUK, J. BARKER, A. BARTOLI, S. BEN ABDELHAMID, M.N. BRADAI, N.K. DULVY, T. FORTIBUONI, I. GIOVOS, D. JIMENEZ ALVARADO, E.K.M. MEYERS, G. MOREY, S. NIEDERMULLER, A. PAULY, F. SERENA \& M. VACCHI. 2019. Mediterranean Angel Sharks: Regional Action Plan. The Shark Trust, United Kingdom. 36 pp.

INTERNATIONAL UNION FOR THE CONSERVATION OF NATURE (IUCN) SHARK SPECIALIST GROUP. 2019. A Special Group of Rays Are Now World's Most Threatened Marine Fish. 18 July, 2019, London, UK. https://www.iucnssg.org/press.html?fbclid=IwAR0vSUQF KmeYxne6kD8RXk8sq8-gbDmkCfvn3GXNUkonSpSB-RzmvKAmanU (Retrieved on the $04 / 08 / 2019$ )

INTERNATIONAL UNION FOR THE CONSERVATION (IUCN). 2018. The IUCN Red List of Threatened Species. Version 2018-1. http://www. iucnredlist.org

MNHN \& UICN France. 2013. La Liste rouge des espèces menacées en France - Chapitre Requins, raies et chimères de France métropolitaine. Paris, France. Rapport d'évaluation, pp. 1-12.

MOREY, G., J.BARKER,A. HOOD, C. GORDON,A.BARTOLI, E.K.M. MEYER, J. ELLIS, R. SHARP, D. JIMENEZ-ALVARADO \& R. POLLOM. 2019. Squatina 
squatina. The IUCN Red List of Threatened Species 2019: e.T39332A117498371. http:// dx.doi.org/10.2305/IUCN.UK.2019-1.RLTS. T39332A117498371.en. Downloaded on 04 August 2019.

LIPEJ, L., A. DE MADDALENA \& A. SOLDO. 2004. Sharks of the Adriatic Sea. Knjižnica Annales Majora, Koper, p. 253.

QUERO, J. \& O. CENDRERO. 1995. Historique de la rarefaction des poissons marins (incidence des activites de pêche sur les poissons dans les eaux marines d'Arcachon du 18eme siecle a nos jours). Comm. des Comm. Eur. DG-XIV-C1, pp. 1-126.

RAFRARI-NOUIRA, S., Y. DIATTA, A. DIABY \& C. CAPAPÉ. 2019. Additional Records of Rare Sharks from Northern Tunisia (Central Mediterranean Sea). Annales, 29 (1): 25-31.

SOLDO, A. \& M. BARICHE. 2016. Squatina aculea$\mathrm{ta}$. The IUCN Red List of Threatened Species 2016: e.T61417A16569265. Downloaded on 04 August 2019.

Received: 17 September 2019

Accepted: 11 October 2019

\title{
Novi nalazi kritično ugroženog sklata sivca Squatina squatina (Linnaeus, 1758) s otoka Korzike, Francuska
}

\author{
Matthieu LAPINSKI i Ioannis GIOVOS \\ Kontakte-pošta: ioannis.giovos@isea.com.gr
}

\section{SAŽETAK}

Sklat sivac pripada najugroženijoj obitelji riba na svijetu. U Sredozemlju su prisutne tri vrste koje su suočene s velikim iscrpljivanjem i s nekoliko lokalnih slučajeva izumiranja kao posljedice prekomjerne eksploatacije u ribolovu.

Utvrđeno je u ovom radu 7 dodatnih nalaza sivca sklata Squatina squatina s Korzike koji doprinose novom regionalnom akcijskom planu za očuvanje sklatova u Sredozemnom moru. Većina nalaza uključuje juvenilne primjerke, što ukazuje da bi područje moglo biti hranilište i obitavalište vrste.

Ključne riječi: sklat sivac, Sredozemlje, hrskavičnjaće, Ligursko more, Tirensko more 
